Review Article

\title{
Advances in T Helper 17 Cell Biology: Pathogenic Role and Potential Therapy in Multiple Sclerosis
}

\author{
Elisabetta Volpe, Luca Battistini, and Giovanna Borsellino \\ Neuroimmunology Unit, Santa Lucia Foundation, Via del Fosso di Fiorano 64-65, 00143 Rome, Italy \\ Correspondence should be addressed to Elisabetta Volpe; e.volpe@hsantalucia.it
}

Received 21 September 2015; Accepted 19 November 2015

Academic Editor: Kong Chen

Copyright ( 2015 Elisabetta Volpe et al. This is an open access article distributed under the Creative Commons Attribution License, which permits unrestricted use, distribution, and reproduction in any medium, provided the original work is properly cited.

\begin{abstract}
The discovery of the T helper (Th) 17 lineage, involved in the protection against fungal and extracellular bacterial infections, has profoundly revolutionized our current understanding of $\mathrm{T}$ cell-mediated responses in autoimmune diseases, including multiple sclerosis (MS). Indeed, recent data demonstrate the pathogenic role of Th17 cells in autoimmune disorders. In particular, studies in MS and in its animal model (EAE, experimental autoimmune encephalomyelitis) have revealed a crucial role of Thl7 cells in the pathogenesis of autoimmune demyelinating diseases in both mice and humans. Over the past years, several important aspects concerning Th17 cells have been elucidated, such as the factors which promote or inhibit their differentiation and the effector cytokines which mediate their responses. The identification of the features endowing Th17 cells with high pathogenicity in MS is of particular interest, and discoveries in Th17 cell biology and function could lead to the design of new strategies aimed at modulating the immune response in MS. Here, we will discuss recent advances in this field, with particular focus on the mechanisms conferring pathogenicity in MS and their potential modulation.
\end{abstract}

\section{Introduction}

Differentiation of naive $\mathrm{CD}^{+}{ }^{+} \mathrm{T}$ cells into $\mathrm{T}$ helper (Th) cells with diverse effector functions is crucial for the establishment of an adaptive immune response. Until recently, only two major cell subsets, Th1 and Th2, were used to describe the different adaptive immune responses established to eradicate pathogens [1-3]. Th1 cells induce cell mediated inflammatory responses against intracellular bacteria [4-7], while $\mathrm{Th} 2$ cells activate a protective response against helminth infection [8]. However, persistent or uncontrolled effector $\mathrm{T}$ cell responses are also associated with pathological states and tissue damage: an excessive Th2 cell response is responsible for atopic diseases, such as asthma [9], and an abnormal Th1 cell response can mediate chronic inflammation and is involved in several autoimmune diseases [10, 11]. In 1998 the discovery of $\mathrm{CD}^{+} \mathrm{T}$ cells producing IL-17 [12] unveiled the presence of another subset of Th cells, the Th17 subset, distinct from Th1 and Th2 [13, 14], and its discovery has helped the understanding of immune responses unexplained by the Th1/Th2 paradigm, such as the response against fungi like Candida albicans [15] and extracellular bacteria such as Pseudomonas aeruginosa [16], Klebsiella pneumoniae [17], Streptococcus pneumoniae [18], and Staphylococcus aureus [19], and the development of autoimmune disorders, such as multiple sclerosis (MS), Crohn's disease, psoriasis, and rheumatoid arthritis. The pathogenic role of Th17 cells in autoimmune diseases is supported by both human studies and experiments performed in animal models. Indeed, IL$17 \mathrm{~A}$ is highly expressed in the central nervous system (CNS) lesions and in the blood and cerebrospinal fluid (CSF) of patients with MS [20-24], in the colonic mucosa of patients with ulcerative colitis or Crohn's disease $[25,26]$, in the psoriatic skin $[27,28]$, and in the synovial tissues from rheumatoid arthritis patients [29]. Studies in murine models such as experimental autoimmune encephalomyelitis (EAE) [30], trinitrobenzene sulfuric acid- (TNBS-) induced colitis [31], and antigen or collagen-induced arthritis [32] reveal that the IL-17 pathway plays a pathogenic role in autoimmune disorders. Finally, the concept that Th17 cells are responsible for driving autoimmune inflammation was finally established when EAE, the mouse model of MS, was shown to be induced by passive transfer of IL-17-producing myelin reactive CD4 T cells [33]. 
In this review we discuss our current understanding of the Th17 lineage, focusing on the factors regulating their differentiation, their typical features, their pathological roles in MS, and the potential modulation of their response for therapeutic approaches.

\section{Cytokine Production by Th17 Cells}

IL-17 is the cytokine produced specifically by Th17 cells. IL$17 \mathrm{~A}$ (commonly referred to as IL-17) is part of a cytokine family including IL-17B, IL-17C, IL-17D, IL-17E (also known as IL-25), and IL-17F [34]. All members of the family show some conserved regions: IL-17A and IL-17F (the only cytokines of this family produced by Th17 cells) are the most similar to a $55 \%$ homology and exert similar functions [35]; IL-25 has the sequence with lowest similarity to IL$17 \mathrm{~A}$ (only 16\%) and plays distinct roles in immunity, mainly regulating the Th2 response against helminthic parasites and allergic inflammation [36-38]. IL-17B, IL-17C, and IL-17D have been shown to induce the production of proinflammatory cytokines, but their biological function is largely unknown [39-42]. Recent studies by three different groups have highlighted the function of IL-17C in mucosal immunity and in autoimmune responses [43-45].

Within the IL-17 family of cytokines, the biological function and regulation of IL-17A and IL-17F are the best understood. Both are produced by Th17 cells and can also act as heterodimers [46]. The effective signalling of IL-17A and IL-17F requires the IL-17 receptor (IL-17R), a heteromeric complex consisting of IL-17RA and IL-17RC [47]. Although both receptors are extensively expressed in different tissues and cell types [48-50] functional studies have focused mainly on epithelial cells. Both IL-17A and IL-17F induce epithelial cells to produce granulopoietic colony stimulating factor (G$\mathrm{CSF}$ ), stem cell factors that regulate granulopoiesis, and $\mathrm{CXC}$ chemokines (CXCL1, CXCL2, CXCL5, and CXCL8) responsible for neutrophil recruitment [51-53]. IL-17A increases the expression of mucins such as MUC5AC and MUC5B in primary human bronchial epithelial cells in vitro [54]. In addition, IL-17A also induces the expression of human beta defensin-2 [55] and CCL20 in lung epithelial cells [56]. This cooperative induction of neutrophil recruitment and antimicrobial-peptide production improves epithelialbarrier integrity and may be critical for mucosal host defense against extracellular bacteria and fungi.

Moreover, several studies have documented the role of IL-17 in regulating antibody generation by plasma cells and germinal center and ectopic inducible bronchus-associated lymphoid tissue (iBALT) formation [57-59].

Altogether, these functions of IL-17 make Th17 cells potentially relevant for vaccine development: in experimental models, Th17 cells are effective in providing vaccinationinduced immunity against a range of pathogens, and the identification of Th17-specific antigens for common prevalent pathogens could help formulate a serotype-independent effective vaccination strategy [60].

However, the Th17 cytokine profile is not restricted to IL17 production. In fact, Th17 cells are potentially producers of a broad array of cytokines, including IL-21, IL-22, IL-26,
IL-6, TNF, and in certain conditions also GM-CSF, IL-9, IL10 , and IFN- $\gamma$ [61-70]. Because each of these cytokines has different functions, they collectively affect the global outcome of the Th17 response and generate different Th17 responses (Figure 1).

\section{Stimuli Required for Th17 Cell Differentiation}

Human in vitro studies reveal that dendritic cells (DCs) exposed to bacteria or fungi, but not viruses, elicit strong Th17 responses [62, 80]. Among pathogen-associated molecular patterns (PAMPs), peptidoglycan (TLR2 agonist) $[62,80]$ and its product muramyl dipeptide (NOD2 agonist) [80] are the most potent stimuli for the production of IL-17. In mice, an alternative pattern-recognition pathway activated by fungal infection has also been described, involving the engagement of a C-type lectin receptor, dectin-1, by fungal $\beta$-glucans components of zymosan [81]. Moreover, DCs stimulated with the pure $\beta$-glucan curdlan (dectin-1 agonist) prime T cells for a much higher IL-17 production than does IFN- $\gamma$ [82].

Stimulation of DC by pathogen-derived structures induces the production of cytokines which ultimately drive Th17 cell differentiation $[83,84]$; these cytokines have been identified by using antigen presenting cell- (APC-) free models of $\mathrm{T}$ cell polarization. In mice, several reports have shown that transforming growth factor- $\beta$ (TGF- $\beta$ ) and IL-6 [85-87] have a critical role in inducing Th17 differentiation. Although not necessary, other proinflammatory cytokines such as IL- $1 \beta$, TNF, and IL-21 can enhance this differentiation $[87,88]$. Finally, IL-23 induces expansion of murine Th17 cells both in vitro [87] and in vivo [89] (Figure 1).

Studies on human Th17 cell differentiation have reported a critical role for IL- $\beta$, IL-6, IL-23, and TGF- $\beta[65,66]$. TGF- $\beta$ was also shown to act in synergy with the inflammatory mediator IL-21 in driving Th17 cell differentiation [90]. Moreover, in humans it has been demonstrated that supernatants from DCs stimulated with zymosan or $\beta$-glucan induce the development of Th17 cells with requirements for TGF- $\beta$, IL-1 $\beta$, and IL-6 [91]. Collectively, these studies reveal that similar pathways regulate both human and mouse Th17 cell differentiation [92] (Figure 1).

\section{Transcription Factors Required for Th17 Cell Differentiation}

The key transcription factor involved in the differentiation program of Th17 cells is the retinoic acid-related orphan receptor (ROR) $\gamma \mathrm{t}[93,94]$, a member of the ROR family of nuclear receptors encoded by the RORC gene. Studies in mice [93] and humans $[65,66]$ revealed that ROR $\gamma t$ controls the expression of IL-17A and IL-17F by Th17 cells. However, ROR $\gamma t$ does not regulate all genes related to the Th17 lineage, suggesting that other transcription factors contribute to the expression of genes involved in its functional differentiation.

Although all cytokine pathways involved in Th17 cell differentiation result in the upregulation of ROR $\gamma \mathrm{t}$ expression, IL-6, IL-21, and IL-23 signalling pathways additionally 


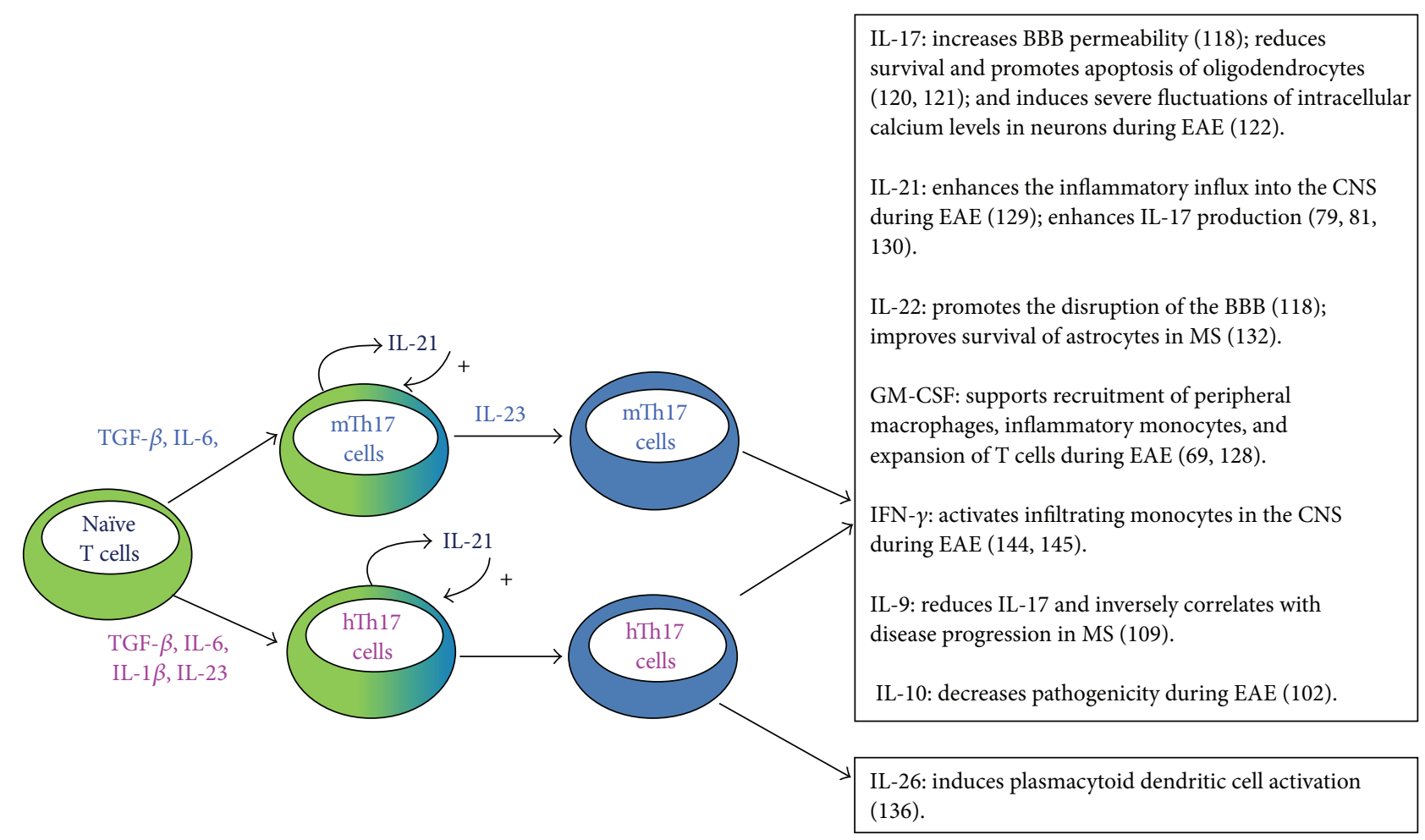

FIGURE 1: Differentiation of Th17 cells and their potential functions in MS. The T helper (Th) 17 cell differentiation program in mice (blue labels) and humans (purple labels) shares significant similarities. In both organisms, IL-6, TGF- $\beta$, IL-23, and IL-21 are involved in complete Th17 differentiation. Human Th17 cell differentiation requires also IL-1 $\beta$. Fully differentiated Th17 cells produce specific sets of cytokines. Both murine and human Th17 cells produce IL-17, IL-21, IL-22, GM-CSF, IFN- $\gamma$, IL-9, and IL-10, with potentially relevant functions in MS pathogenesis. Human Th17 cells also produce IL-26.

activate STAT3, which directly binds the IL-17 and IL-21 promoters $[95,96]$. Cells transduced with both $\operatorname{ROR} \gamma \mathrm{t}$ and an active form of STAT3 (STAT3C) produce more IL-17 per cell, suggesting a cooperation between ROR $\gamma$ t and STAT3 at transcriptional target sites [63]. Patients with autosomaldominant hyper-IgE syndrome associated with dominantnegative mutations in STAT3 lack Th17 cells, revealing the importance of STAT3-dependent signals in the differentiation and/or expansion of human IL-17-producing cells [97].

IRF4 has also been reported to be essential for Th17 cell differentiation [98]. IRF4-deficient mice have an impaired ROR $\gamma$ t induction, since IRF4 is located upstream of ROR $\gamma \mathrm{t}$ in the Th17 cell differentiation process [98].

Another transcription factor known to cooperate with ROR $\gamma \mathrm{t}$ is the basic leucine zipper transcription factor ATF like (BATF), which is upregulated in Th cells following $\mathrm{T}$ cell receptor (TCR) activation $[99,100]$ and which is essential for the maintenance of ROR $\gamma \mathrm{t}$ expression induced by TGF- $\beta$ and IL-6 [100]. Recent studies have identified IRF4 and BATF as "pioneer factors" that bind and govern the accessibility of chromatin, enabling ROR $\gamma$ t recruitment and binding to Th17 signature genes $[101,102]$.

Another member of the ROR family, ROR $\alpha$, also contributes to mouse Th17 cell development, and coexpression of $\operatorname{ROR} \alpha$ and $\operatorname{ROR} \gamma \mathrm{t}$ causes synergistic increases in IL17A, IL-17F, and IL-23R expression [103]. ROR $\alpha$ and ROR $\gamma \mathrm{t}$ bind to the same retinoid response-like elements individually or as heterodimers and may be functionally redundant [104].

Retinoic acid receptors can be regulated by the liganddependent transcription factor aryl hydrocarbon receptor (AHR) $[105,106]$, whose binding to environmental pollutants such as dioxin influence Th17 cell differentiation [107, 108]. Different cellular contexts might provide distinct transcriptional partners for AHR and determine diverse outcomes of the immune response.

Another transcription factor associated with environmental conditions is the hypoxia-inducible factor $1 \alpha$ (HIF1 $\alpha)$, which is a key sensor of hypoxia. HIFl $\alpha$ directly binds and drives transcription of RORC [109], and lack of HIFl $\alpha$ results in diminished Th17 development [110].

Therefore, combinatorial interactions of multiple transcription factors, including $\mathrm{ROR} \gamma \mathrm{t}, \mathrm{ROR} \alpha$, activated STAT3, IRF4, BATF, AHR, HIFl $\alpha$, and other unidentified factors regulate the genes that define the Thl7 lineage. Decoding this transcriptional network will provide a better understanding of pathways involved in the differentiation of Th17 cells and may facilitate the development of strategies to manipulate the immune responses associated with these cells.

\section{Immunomodulation of Th17 Responses}

The conjunct action of multiple soluble factors fine-tunes and regulates the outcome of immune responses. For instance, 
IL-10 has an important immunomodulatory role during the Th17 response. In fact, IL-10 production by restimulated mouse Th17 cells in the presence of TGF- $\beta$ and IL- 6 is able to regulate Th17 cell immunopathology and reduces EAE disease severity [111]. In contrast, restimulation in the presence of IL-23 does not induce IL-10 production, conferring pathogenic functions to Th17 cells [111]. Thus, IL-10 production in Th17-polarizing conditions may be a mechanism of self-regulation of the potentially dangerous Th17 cell response. In humans, the regulation of IL-10 production in Th17 conditions is dependent on IL-1 $\beta[65$, 112]. Human Th17 cell differentiation in the presence of IL$1 \beta$ results in an enhancement of IL-17 and in a decrease of IL-10 production suggesting that, during the resolution of inflammation, a decrease in or a lack of IL- $1 \beta$ may simultaneously decrease the production of IL-17 and enhance the production of IL-10 $[65,112]$. Moreover, several studies suggest that IL-10 inhibits differentiation of Th17 cells in a direct manner $[113,114]$. Given the role of IL-10 as a potent negative regulator of inflammation $[115,116]$, its presence could be an important mechanism for controlling the Th17 response.

The cytokine IL-2 has a similar inhibitory effect on Th17 cell differentiation. In fact, addition of exogenous IL2 reduces the proportion of murine Th17 cells differentiated from naive $\mathrm{T}$ cells in the presence of TGF- $\beta$ and IL-6, whereas inversely blocking autocrine IL- 2 by the addition of neutralizing antibodies enhances Th17 differentiation. Furthermore, IL-2-deficient mice contain a substantially greater fraction of Th17 T cells, and in vitro stimulation of $\mathrm{T}$ cells from these mice results in higher proportions of IL-17-producing cells [117]. In contrast, IL-2 seems to have a positive effect on IL-17 expression by human Th17 cells, and the addition of an IL-2-blocking antibody during differentiation prevents cell proliferation and IL-17 production [66].

We recently demonstrated that IL-9 has an inhibitory effect on IL-17 production by human Th17-polarized cells. Importantly, the interaction between IL-17 and IL-9 reveals a decisive mechanism regulating the pathogenic inflammation generated by Th17 cells in MS [118]. In fact, we found that IL-9 level in the CSF of MS patients inversely correlates with the progression of MS and with the levels of IL-17 observed in the CSF, indicating that inhibition of IL-17 via IL-9 could be protective in MS [118], despite the controversial results on the role of IL-9 in EAE $[68,119]$.

Th17 responses can also be suppressed by antigen presenting cells producing IL-27: this cytokine inhibits IL-17 production by human and mouse Th17 cells [120]. Interestingly, plasma levels of IL-27 negatively correlate with the percentage of circulating Th17 or with plasma IL-17 concentration in patients with progressive MS, suggesting that IL-27 might be involved in this disease [121].

Thus, the establishment, progression, and outcome of chronic inflammation, which underlies the pathogenesis of MS, are highly dependent on the nature of the complex network of cytokines which modulate Th17 cells and which are produced during the immune response.

\section{Pathogenic Role of Th17 Cells in Multiple Sclerosis}

MS is a heterogenous disease characterized by a wide variety of neurological symptoms and signs attributed to discrete areas of inflammation, demyelination, and axonal loss in the CNS [122]. Two main courses of MS exist: relapsing-remitting (RR) and primary or secondary progressive (PP and SP). RR-MS is characterized by recurrent neurologic symptoms interspersed by periods of stability, with full or partial recovery; the progressive form is characterized by gradual neurological dysfunction with or without exacerbations [123, 124].

Immunological mechanisms such as myelin destruction by specific CD8 T cells, activated microglia, invading macrophages, natural killer cells, and autoantibodies produced by $\mathrm{B}$ cells contribute to demyelination and axonal loss. Importantly, Th17 cells are mainly responsible for the persistent inflammation that characterizes both forms of MS [122].

Among the typical features of Th17 cells that could confer pathogenicity to MS, their abilities to enter the encephalic compartment, to penetrate the blood brain barrier (BBB), and to recruit inflammatory cells have been documented. In particular, Th17 cells express high levels of the C-C chemokine receptor 6 (CCR6) on the cell surface $[62,125]$ that binds the C-C chemokine ligand 20 (CCL20) constitutively expressed by the vascular endothelium of the bloodcerebrospinal barrier, thus enabling the entry of Th17 cells into the encephalic compartment through the choroid plexus [125]. Once in the brain parenchyma, Th17 cells release several proinflammatory mediators including IL-17A, responsible for the downregulation of tight junction proteins of the $\mathrm{BBB}$, increasing $\mathrm{BBB}$ permeability, and favoring migration of both soluble inflammatory molecules and other circulating immune cells into the CNS [126]. Consistent with murine studies, IL-17A levels in the CSF of MS patients are associated with neutrophil expansion and blood brain barrier disruption, indicating that IL-17 may have similar pathogenic roles in EAE and MS [127].

It has been proposed that IL-17 also interferes with remyelinating processes, reducing survival [128], and promoting apoptosis of oligodendrocytes, the myelin-forming cells [129]. Moreover, a potential neurotoxic effect of Th17 cells has also been reported, by the induction of severe fluctuations of intracellular calcium levels in neurons during EAE [130] or through the release of granzyme B in human fetal neurons [126].

However, murine studies suggest that not only production of IL-17, but also other features of Th17 cells collectively confer encephalitogenic potential to these cells in MS. In fact, the course of EAE is unperturbed or only lightly ameliorated in IL-17 knockout mice and in wild-type mice treated with neutralizing antibodies specific for IL-17A [131, 132].

Among the proinflammatory mediators produced by Th17 cells, GM-CSF is gaining much attention in MS pathogenesis. Recent studies have suggested that this cytokine plays a fundamental role in the pathogenicity of Th17 cells in EAE $[69,70]$. In fact, GM-CSF-deficient mice are resistant to EAE 
$[69,133]$ and GM-CSF production by Th17 cells is crucial for their capacity to induce EAE [70, 134], likely supporting recruitment of peripheral macrophages, inflammatory monocytes, and expansion of T cells $[69,135,136]$.

Another cytokine produced by Th17 cells is IL-21, whose administration before induction of EAE enhances the inflammatory influx into the CNS as well as the severity of the disease [137], likely due to the role of IL-21 in the induction and expansion of Th17 cells [88, 90, 138]. Interestingly, IL-21 and its receptor have been detected in lymphocytes infiltrating acute and chronic active white matter MS lesions [139], underlining the role for this cytokine in CNS inflammation.

The role of IL-22 in MS is still unclear. High levels of IL-22 and of IL-22 producing cells have been detected in the serum, CSF, and peripheral blood of MS patients [140-142], and it has been demonstrated that IL-22 promotes the disruption of $\mathrm{BBB}$ in vitro and in vivo [126]. However, in the brain tissue IL-22 improves survival of astrocytes that express its receptor [140], thus suggesting a protective role of this cytokine in MS.

Among the cytokines produced by Th17 cells, IL-26 has never been studied in the context of brain inflammation, due to the fact that only human Th17 cells produce it, thus making the EAE model inappropriate. However, the identification of a risk locus containing IL26 and single-nucleotide polymorphisms within the IL26 gene region associated with MS [143] encourages the study of its role in MS. Interestingly, IL-26 forms complexes with bacterial DNA and self-DNA released by dying cells, thus inducing plasmacytoid dendritic cells to produce IFN- $\alpha$ [144], that could have important implications in the modulation of the autoimmune response.

Moreover, the potential pathogenic role of Th17 cells in MS and in other autoimmune disorders could be related to their enhanced capability to survive, self-renew, generate effector progeny, and enter the memory pool with an efficiency superior to that of Th1 cells [145], and to their resistance to activation induced cell death [146-148]. In particular, we have recently demonstrated that human Th17 cells derived from healthy donors and MS patients express lower levels of FASL compared to Thl cells, with a consequent lower sensitivity to cell death [148]. This mechanism could explain the persistence of IL-17-producing cells in autoimmune diseases, such as MS, contributing to the chronic inflammation typical of the disease.

Interestingly, Th17 cells could play a pathogenic role in MS also by converting their phenotype into a proinflammatory Th1 profile, as demonstrated by IL-17F reporter mice, where committed Th17 cells give rise to a progeny that shifts toward enhanced IFN- $\gamma$ expression, contingent upon limited or absent TGF- $\beta$ [149].

Similarly, in humans there are evidences indicating that, in the presence of IL-12, Th17 cells produce also IFN- $\gamma$. These cells which produce both IL-17 and IFN- $\gamma$, called Th1/17 cells [26], together with "nonclassical Thl cells" might contribute to disease pathogenesis through properties shared by both the Th1 and Th17 subsets [150]. Moreover, Th17 cells producing IFN- $\gamma$ are enriched in myelin oligodendrocyte glycoproteinspecific T cells [151]. IFN- $\gamma$ produced by these cells could strongly activate macrophages [152] whose infiltration in the CNS correlates with EAE severity [153].

\section{Therapeutic Approaches Targeting Th17 Cells in MS}

In recent years several therapies directed against Th17-related cytokines, including IL-17, IL-23, and GM-CSF, have been developed, and some are currently being tested in ongoing clinical trials (Table 1). The fully humanized antibody neutralizing IL-17A called AIN457 or Secukinumab (NCT01708603 Clinicaltrial.gov) is already approved for the first-line systemic treatment of moderate to severe plaque psoriasis [154, $155]$; in MS patients, although it showed a reduction by $63 \%$ of new magnetic resonance imaging (MRI) lesions compared to placebo-treated patients, the reduction of annualized relapse rate (ARR) was not statistically significant [71]. Moreover, Secukinumab was ineffective and resulted in higher rates of adverse events, mainly infections, compared with placebo in patients with Crohn's disease [156], and the study in MS terminated early based upon development of another anti-IL17 monoclonal antibody with better potential for treating MS patients, Ixekizumab (NCT02387801 Clinicaltrial.gov).

Another Th17-related cytokine that has recently gained attention, as a promising molecular target, is GM-CSF, and MOR103 (NCT01517282 Clinicaltrial.gov) a fully human monoclonal antibody against human GM-CSF was tested in clinical trials. However, although performed on a limited number of patients, the first clinical trial did not show efficacy in MS [73].

Selective targeting of single Th17 cytokines, such as IL17 or GM-CSF, with monoclonal antibodies has not shown efficacy in MS and in other autoimmune diseases such as Crohn's disease and rheumatoid arthritis, although the involvement of Th17 cells in their pathogenesis has been widely documented. This suggests that Th17 cells' pathogenicity relies also on other factors, and thus targeting this $\mathrm{T}$ cell subset, inhibiting the Th17 differentiation program as a whole, may be more effective in limiting inflammation.

In this context, Ustekinumab, an antibody neutralizing the p40 subunit common to IL-12 and IL-23, was developed but the clinical trial has been completed and did not show efficacy in reducing inflammation in MS (NCT00207727 Clinicaltrial.gov) [74-76]. However, by blocking both IL-12 and IL-23 which sit upstream of the Th1 and Th17 differentiation program, respectively, this monoclonal antibody suppressed both of these responses and this could explain its low efficacy in MS, considering that interference with Th1 responses determines increased susceptibility rather than protection from EAE [157-159]. Specific inhibitors of the p19 subunit of IL-23, including Tildrakizumab, Guselkumab, AMG 139, BI 655066, and LY3074828, that have been developed and are being currently tested in other autoimmune diseases [72] could give encouraging results in MS treatment.

The ROR $\gamma \mathrm{t}$ transcription factor represents the ideal target for the manipulation of Th17 cell responses. Digoxin, a small molecule which binds ROR $\gamma$ t and interferes with transcription, has been shown to inhibit Th17 cell differentiation in the mouse and to reduce EAE severity [77], and another natural product, ursolic acid, has similar effects [78]. Chemical modification of other small molecules shown to bind the ligand-binding domains of $\operatorname{ROR} \alpha$ and $\operatorname{ROR} \gamma t$ has 
TABLE 1: Therapeutic approaches targeting Th17 cells in MS.

\begin{tabular}{|c|c|c|c|c|}
\hline Agent & Functional role & $\begin{array}{c}\text { Clinical trial } \\
\text { identifier in MS } \\
\end{array}$ & Clinical stage & Reference \\
\hline Secukinumab (AIN457) & Neutralizes IL-17A & NCT01708603 & $\begin{array}{c}\text { 63\% reduction of new MRI lesions compared } \\
\text { to placebo; ARR reduction not statistically } \\
\text { significant }\end{array}$ & {$[71]$} \\
\hline Ixekizumab & Neutralizes IL-17 & & Currently tested in psoriasis & [72] \\
\hline MOR103 & $\begin{array}{c}\text { Neutralizes } \\
\text { GM-CSF }\end{array}$ & NCT01517282 & Did not show efficacy in MS & [73] \\
\hline Ustekinumab & $\begin{array}{l}\text { Neutralizes the } \mathrm{p} 40 \\
\text { subunit common } \\
\text { to IL-12 and IL-23 }\end{array}$ & NCT00207727 & Did not show efficacy in MS & {$[74-76]$} \\
\hline Tildrakizumab & $\begin{array}{l}\text { Neutralizes the p19 } \\
\text { subunit specific of } \\
\text { IL-23 }\end{array}$ & & Currently tested in other autoimmune diseases & {$[72]$} \\
\hline Guselkumab & $\begin{array}{l}\text { Neutralizes the p19 } \\
\text { subunit specific of } \\
\text { IL-23 }\end{array}$ & & Currently tested in other autoimmune diseases & [72] \\
\hline AMG 139 & $\begin{array}{l}\text { Neutralizes the p19 } \\
\text { subunit specific of } \\
\text { IL-23 }\end{array}$ & & Currently tested in other autoimmune diseases & {$[72]$} \\
\hline BI 655066 & $\begin{array}{l}\text { Neutralizes the p19 } \\
\text { subunit specific of } \\
\text { IL-23 }\end{array}$ & & Currently tested in other autoimmune diseases & [72] \\
\hline LY3074828 & $\begin{array}{l}\text { Neutralizes the p19 } \\
\text { subunit specific of } \\
\text { IL-23 }\end{array}$ & & Currently tested in other autoimmune diseases & {$[72]$} \\
\hline Digoxin & $\begin{array}{c}\text { Interferes with } \\
\text { ROR } \gamma \mathrm{t} \\
\end{array}$ & & Preclinical phase & {$[77]$} \\
\hline Ursolic acid & $\begin{array}{c}\text { Interferes with } \\
\text { ROR } \gamma \mathrm{t} \\
\end{array}$ & & Preclinical phase & {$[78]$} \\
\hline SR1001 & $\begin{array}{c}\text { Interferes with } \\
\mathrm{ROR} \alpha \text { and } \mathrm{ROR} \gamma \mathrm{t}\end{array}$ & & Preclinical phase & {$[79]$} \\
\hline
\end{tabular}

led to the development of SR1001, which reduces human and murine Th17 cell differentiation, and suppresses the clinical severity of autoimmune disease in mice [79]. Although still in preclinical phase, the results of these studies indicate that this novel class of compounds has potential utility in the treatment of autoimmune diseases.

\section{Conclusions}

Over the past few years, remarkable advances in the understanding of Th responses have been reported. The discovery of the Th17 subset, of the cytokines and transcriptional factors regulating its differentiation, and of the biological functions of its effector cytokines has advanced our understanding of the role of $\mathrm{CD}^{+} \mathrm{T}$ cells in adaptive immunity. However, many issues remain to be addressed, especially concerning the balance between pathological and protective roles during autoimmune and infectious diseases. Advances in these points are critical for the future development of new therapeutic strategies able to modulate Th17 pathways for the treatment of MS and of diseases where Th17 cells play a pathogenic role.

\section{Conflict of Interests}

The authors declare that they have no financial conflict of interests.

\section{References}

[1] R. L. Coffman, "Origins of the $\mathrm{T}(\mathrm{H}) 1-\mathrm{T}(\mathrm{H}) 2$ model: a personal perspective," Nature Immunology, vol. 7, no. 6, pp. 539-541, 2006.

[2] T. R. Mosmann, H. Cherwinski, M. W. Bond, M. A. Giedlin, and R. L. Coffman, "Two types of murine helper T cell clone. I. Definition according to profiles of lymphokine activities and secreted proteins," Journal of Immunology, vol. 136, pp. 23482357, 1986.

[3] T. R. Mosmann and R. L. Coffman, "TH1 and TH2 cells: different patterns of lymphokine secretion lead to different functional properties," Annual Review of Immunology, vol. 7, pp. 145-173, 1989.

[4] C. A. Scanga, J. Aliberti, D. Jankovic et al., "Cutting edge: MyD88 is required for resistance to Toxoplasma gondii infection and regulates parasite-induced IL-12 production by dendritic 
cells," Journal of Immunology, vol. 168, no. 12, pp. 5997-6001, 2002.

[5] E. Seki, H. Tsutsui, N. M. Tsuji et al., "Critical roles of myeloid differentiation factor 88-dependent proinflammatory cytokine release in early phase clearance of Listeria monocytogenes in mice," Journal of Immunology, vol. 169, no. 7, pp. 3863-3868, 2002.

[6] D. Sacks and N. Noben-Trauth, "The immunology of susceptibility and resistance to Leishmania major in mice," Nature Reviews Immunology, vol. 2, no. 11, pp. 845-858, 2002.

[7] C. M. Fremond, V. Yeremeev, D. M. Nicolle, M. Jacobs, V. F. Quesniaux, and B. Ryffel, "Fatal Mycobacterium tuberculosis infection despite adaptive immune response in the absence of MyD88," The Journal of Clinical Investigation, vol. 114, no. 12, pp. 1790-1799, 2004.

[8] R. M. Anthony, L. I. Rutitzky, J. F. Urban, M. J. Stadecker, and W. C. Gause, "Protective immune mechanisms in helminth infection," Nature Reviews Immunology, vol. 7, no. 12, pp. 975987, 2007.

[9] L. Cohn, J. A. Elias, and G. L. Chupp, "Asthma: mechanisms of disease persistence and progression," Annual Review of Immunology, vol. 22, pp. 789-815, 2004.

[10] G. Bouma and W. Strober, "The immunological and genetic basis of inflammatory bowel disease," Nature Reviews Immunology, vol. 3, no. 7, pp. 521-533, 2003.

[11] M. A. Lowes, A. M. Bowcock, and J. G. Krueger, "Pathogenesis and therapy of psoriasis," Nature, vol. 445, no. 7130, pp. 866-873, 2007.

[12] D. V. Jovanovic, J. A. Di Battista, J. Martel-Pelletier et al., "IL-17 stimulates the production and expression of proinflammatory cytokines, IL- $\beta$ and TNF- $\alpha$, by human macrophages," Journal of Immunology, vol. 160, no. 7, pp. 3513-3521, 1998.

[13] H. Park, Z. Li, X. O. Yang et al., "A distinct lineage of CD4 T cells regulates tissue inflammation by producing interleukin 17," Nature Immunology, vol. 6, no. 11, pp. 1133-1141, 2005.

[14] L. E. Harrington, R. D. Hatton, P. R. Mangan et al., "Interleukin 17-producing $\mathrm{CD}^{+}$effector T cells develop via a lineage distinct from the T helper type 1 and 2 lineages," Nature Immunology, vol. 6, no. 11, pp. 1123-1132, 2005.

[15] W. Huang, L. Na, P. L. Fidel, and P. Schwarzenberger, "Requirement of interleukin-17A for systemic anti-Candida albicans host defense in mice," Journal of Infectious Diseases, vol. 190, no. 3, pp. 624-631, 2004.

[16] J. Liu, Y. Feng, K. Yang et al., "Early production of IL-17 protects against acute pulmonary Pseudomonas aeruginosa infection in mice," FEMS Immunology and Medical Microbiology, vol. 61, no. 2, pp. 179-188, 2011.

[17] P. Ye, P. B. Garvey, P. Zhang et al., "Interleukin-17 and lung host defense against Klebsiella pneumoniae infection," American Journal of Respiratory Cell and Molecular Biology, vol. 25, no. 3, pp. 335-340, 2001.

[18] Y.-J. Lu, J. Gross, D. Bogaert et al., "Interleukin-17A mediates acquired immunity to pneumococcal colonization," PLoS Pathogens, vol. 4, no. 9, Article ID e1000159, 2008.

[19] C. P. Montgomery, M. Daniels, F. Zhao, M.-L. Alegre, A. S. Chong, and R. S. Daum, "Protective immunity against recurrent Staphylococcus aureus skin infection requires antibody and interleukin-17A," Infection and Immunity, vol. 82, no. 5, pp. 2125-2134, 2014.

[20] C. Lock, G. Hermans, R. Pedotti et al., "Gene-microarray analysis of multiple sclerosis lesions yields new targets validated in autoimmune encephalomyelitis," Nature Medicine, vol. 8, no. 5, pp. 500-508, 2002.

[21] J. S. Tzartos, M. A. Friese, M. J. Craner et al., "Interleukin-17 production in central nervous system-infiltrating $\mathrm{T}$ cells and glial cells is associated with active disease in multiple sclerosis," The American Journal of Pathology, vol. 172, no. 1, pp. 146-155, 2008.

[22] L. Durelli, P. Barbero, A. Cucci et al., "Neutralizing antibodies in multiple sclerosis patients treated with $375 \mu \mathrm{g}$ interferon- $\beta$ - $1 \mathrm{~b}$," Expert Opinion on Biological Therapy, vol. 9, no. 4, pp. 387-397, 2009.

[23] V. Brucklacher-Waldert, K. Stuerner, M. Kolster, J. Wolthausen, and E. Tolosa, "Phenotypical and functional characterization of T helper 17 cells in multiple sclerosis," Brain, vol. 132, no. 12, pp. 3329-3341, 2009.

[24] L. Durelli, L. Conti, M. Clerico et al., "T-helper 17 cells expand in multiple sclerosis and are inhibited by interferon- $\beta$," Annals of Neurology, vol. 65, no. 5, pp. 499-509, 2009.

[25] S. Fujino, A. Andoh, S. Bamba et al., "Increased expression of interleukin 17 in inflammatory bowel disease," Gut, vol. 52, no. 1, pp. 65-70, 2003.

[26] F. Annunziato, L. Cosmi, V. Santarlasci et al., "Phenotypic and functional features of human Th17 cells," Journal of Experimental Medicine, vol. 204, no. 8, pp. 1849-1861, 2007.

[27] M. B. M. Teunissen, C. W. Koomen, R. de Waal Malefyt, E. A. Wierenga, and J. D. Bos, "Interleukin-17 and interferon$\gamma$ synergize in the enhancement of proinflammatory cytokine production by human keratinocytes," The Journal of Investigative Dermatology, vol. 111, no. 4, pp. 645-649, 1998.

[28] N. J. Wilson, K. Boniface, J. R. Chan et al., "Development, cytokine profile and function of human interleukin 17producing helper T cells," Nature Immunology, vol. 8, no. 9, pp. 950-957, 2007.

[29] S. Kotake, N. Udagawa, N. Takahashi et al., "IL-17 in synovial fluids from patients with rheumatoid arthritis is a potent stimulator of osteoclastogenesis," The Journal of Clinical Investigation, vol. 103, no. 9, pp. 1345-1352, 1999.

[30] D. J. Cua, J. Sherlock, Y. Chen et al., "Interleukin-23 rather than interleukin-12 is the critical cytokine for autoimmune inflammation of the brain," Nature, vol. 421, no. 6924, pp. 744748, 2003.

[31] Z. Zhang, M. Zheng, J. Bindas, P. Schwarzenberger, and J. K. Kolls, "Critical role of IL-17 receptor signaling in acute TNBSinduced colitis," Inflammatory Bowel Diseases, vol. 12, no. 5, pp. 382-388, 2006.

[32] E. Lubberts, M. I. Koenders, B. Oppers-Walgreen et al., "Treatment with a neutralizing anti-murine interleukin-17 antibody after the onset of collagen-induced arthritis reduces joint inflammation, cartilage destruction, and bone erosion," Arthritis and Rheumatism, vol. 50, no. 2, pp. 650-659, 2004.

[33] C. L. Langrish, Y. Chen, W. M. Blumenschein et al., "IL-23 drives a pathogenic $\mathrm{T}$ cell population that induces autoimmune inflammation," The Journal of Experimental Medicine, vol. 201, no. 2, pp. 233-240, 2005.

[34] W. Jin and C. Dong, "IL-17 cytokines in immunity and inflammation," Emerging Microbes \& Infections, vol. 2, no. 9, article e60, 2013.

[35] S. G. Hymowitz, E. H. Filvaroff, J. Yin et al., "IL-17s adopt a cystine knot fold: structure and activity of a novel cytokine, IL17F, and implications for receptor binding," The EMBO Journal, vol. 20, no. 19, pp. 5332-5341, 2001. 
[36] P. G. Fallon, S. J. Ballantyne, N. E. Mangan et al., "Identification of an interleukin (IL)-25-dependent cell population that provides IL-4, IL-5, and IL-13 at the onset of helminth expulsion," The Journal of Experimental Medicine, vol. 203, no. 4, pp. 11051116, 2006.

[37] A. M. Owyang, C. Zaph, E. H. Wilson et al., "Interleukin 25 regulates type 2 cytokine-dependent immunity and limits chronic inflammation in the gastrointestinal tract," The Journal of Experimental Medicine, vol. 203, no. 4, pp. 843-849, 2006.

[38] M. M. Fort, J. Cheung, D. Yen et al., "IL-25 induces IL-4, IL5, and IL-13 and Th2-associated pathologies in vivo," Immunity, vol. 15, no. 6, pp. 985-995, 2001.

[39] Y. Yamaguchi, K. Fujio, H. Shoda et al., "IL-17B and IL-17C are associated with TNF- $\alpha$ production and contribute to the exacerbation of inflammatory arthritis," Journal of Immunology, vol. 179, no. 10, pp. 7128-7136, 2007.

[40] Q. Wu, R. J. Martin, J. G. Rino, R. Breed, R. M. Torres, and H. W. Chu, "IL-23-dependent IL-17 production is essential in neutrophil recruitment and activity in mouse lung defense against respiratory Mycoplasma pneumoniae infection," Microbes and Infection, vol. 9, no. 1, pp. 78-86, 2007.

[41] H. Li, J. Chen, A. Huang et al., "Cloning and characterization of IL-17B and IL-17C, two new members of the IL-17 cytokine family," Proceedings of the National Academy of Sciences of the United States of America, vol. 97, no. 2, pp. 773-778, 2000.

[42] T. Starnes, H. E. Broxmeyer, M. J. Robertson, and R. Hromas, "Cutting edge: IL-17D, a novel member of the IL-17 family, stimulates cytokine production and inhibits hemopoiesis," Journal of Immunology, vol. 169, no. 2, pp. 642-646, 2002.

[43] V. Ramirez-Carrozzi, A. Sambandam, E. Luis et al., "IL-17C regulates the innate immune function of epithelial cells in an autocrine manner," Nature Immunology, vol. 12, no. 12, pp. 11591166, 2011.

[44] X. Song, S. Zhu, P. Shi et al., "IL-17RE is the functional receptor for IL-17C and mediates mucosal immunity to infection with intestinal pathogens," Nature Immunology, vol. 12, no. 12, pp. 1151-1158, 2011.

[45] S. H. Chang, J. M. Reynolds, B. P. Pappu, G. Chen, G. J. Martinez, and C. Dong, "Interleukin-17C promotes Th17 cell responses and autoimmune disease via interleukin-17 receptor E," Immunity, vol. 35, no. 4, pp. 611-621, 2011.

[46] S. C. Liang, A. J. Long, F. Bennett et al., "An IL-17F/A heterodimer protein is produced by mouse Th17 cells and induces airway neutrophil recruitment," Journal of Immunology, vol. 179, no. 11, pp. 7791-7799, 2007.

[47] D. Toy, D. Kugler, M. Wolfson et al., "Cutting edge: interleukin 17 signals through a heteromeric receptor complex," Journal of Immunology, vol. 177, no. 1, pp. 36-39, 2006.

[48] D. Haudenschild, T. Moseley, L. Rose, and A. H. Reddi, "Soluble and transmembrane isoforms of novel interleukin-17 receptorlike protein by RNA splicing and expression in prostate cancer," The Journal of Biological Chemistry, vol. 277, no. 6, pp. 43094316, 2002.

[49] Z. Yao, S. L. Painter, W. C. Fanslow et al., "Human IL-17: a novel cytokine derived from T cells," Journal of Immunology, vol. 155, no. 12 , pp. 5483-5486, 1995.

[50] T. A. Moseley, D. R. Haudenschild, L. Rose, and A. H. Reddi, "Interleukin-17 family and IL-17 receptors," Cytokine \& Growth Factor Reviews, vol. 14, no. 2, pp. 155-174, 2003.

[51] F. Fossiez, O. Djossou, P. Chomarat et al., "T cell interleukin17 induces stromal cells to produce proinflammatory and hematopoietic cytokines," The Journal of Experimental Medicine, vol. 183, no. 6, pp. 2593-2603, 1996.

[52] C. E. Jones and K. Chan, "Interleukin-17 stimulates the expression of interleukin-8, growth-related oncogene-alpha, and granulocyte-colony-stimulating factor by human airway epithelial cells," American Journal of Respiratory Cell and Molecular Biology, vol. 26, no. 6, pp. 748-753, 2002.

[53] M. Laan, Z.-H. Cui, H. Hoshino et al., "Neutrophil recruitment by human IL-17 via C-X-C chemokine release in the airways," Journal of Immunology, vol. 162, no. 4, pp. 2347-2352, 1999.

[54] Y. Chen, P. Thai, Y.-H. Zhao, Y.-S. Ho, M. M. DeSouza, and $\mathrm{R}$. $\mathrm{Wu}$, "Stimulation of airway mucin gene expression by interleukin (IL)-17 through IL-6 paracrine/autocrine loop," Journal of Biological Chemistry, vol. 278, no. 19, pp. 17036-17043, 2003.

[55] C.-Y. Kao, Y. Chen, P. Thai et al., "IL-17 markedly up-regulates $\beta$ defensin-2 expression in human airway epithelium via JAK and NF- $\kappa$ B signaling pathways," Journal of Immunology, vol. 173, no. 5, pp. 3482-3491, 2004.

[56] F. Huang, C.-Y. Kao, S. Wachi, P. Thai, J. Ryu, and R. Wu, "Requirement for both JAK-mediated PI3K signaling and ACT1/TRAF6/TAK1-dependent NF- $\kappa$ B activation by IL-17A in enhancing cytokine expression in human airway epithelial cells," Journal of Immunology, vol. 179, no. 10, pp. 6504-6513, 2007.

[57] H.-C. Hsu, P. Yang, J. Wang et al., "Interleukin 17-producing $\mathrm{T}$ helper cells and interleukin 17 orchestrate autoreactive germinal center development in autoimmune BXD2 mice," Nature Immunology, vol. 9, no. 2, pp. 166-175, 2008.

[58] A. Doreau, A. Belot, J. Bastid et al., "Interleukin 17 acts in synergy with B cell-activating factor to influence B cell biology and the pathophysiology of systemic lupus erythematosus," Nature Immunology, vol. 10, no. 7, pp. 778-785, 2009.

[59] M. Mitsdoerffer, Y. Lee, A. Jäger et al., "Proinflammatory T helper type 17 cells are effective B-cell helpers," Proceedings of the National Academy of Sciences of the United States of America, vol. 107, no. 32, pp. 14292-14297, 2010.

[60] P. Kumar, K. Chen, and J. K. Kolls, "Th17 cell based vaccines in mucosal immunity," Current Opinion in Immunology, vol. 25, no. 3, pp. 373-380, 2013.

[61] S. C. Liang, X.-Y. Tan, D. P. Luxenberg et al., "Interleukin (IL)22 and IL-17 are coexpressed by Th17 cells and cooperatively enhance expression of antimicrobial peptides," The Journal of Experimental Medicine, vol. 203, no. 10, pp. 2271-2279, 2006.

[62] E. V. Acosta-Rodriguez, G. Napolitani, A. Lanzavecchia, and F. Sallusto, "Interleukins $1 \beta$ and 6 but not transforming growth factor- $\beta$ are essential for the differentiation of interleukin 17producing human T helper cells," Nature Immunology, vol. 8, no. 9, pp. 942-949, 2007.

[63] L. Zhou, I. I. Ivanov, R. Spolski et al., "IL-6 programs $\mathrm{T}_{H}-17$ cell differentiation by promoting sequential engagement of the IL21 and IL-23 pathways," Nature Immunology, vol. 8, no. 9, pp. 967-974, 2007.

[64] A. Laurence and J. J. O'Shea, “TH-17 differentiation: of mice and men," Nature Immunology, vol. 8, no. 9, pp. 903-905, 2007.

[65] E. Volpe, N. Servant, R. Zollinger et al., "A critical function for transforming growth factor-beta, interleukin 23 and proinflammatory cytokines in driving and modulating human $\mathrm{T}_{\mathrm{H}}-17$ responses," Nature Immunology, vol. 9, no. 6, pp. 650-657, 2008.

[66] N. Manel, D. Unutmaz, and D. R. Littman, "The differentiation of human $\mathrm{T}_{H}-17$ cells requires transforming growth factor- $\beta$ 
and induction of the nuclear receptor ROR $\gamma \mathrm{t}$," Nature Immunology, vol. 9, no. 6, pp. 641-649, 2008.

[67] E. Volpe, M. Touzot, N. Servant et al., "Multiparametric analysis of cytokine-driven human Th17 differentiation reveals a differential regulation of IL-17 and IL-22 production," Blood, vol. 114, no. 17, pp. 3610-3614, 2009.

[68] W. Elyaman, E. M. Bradshaw, C. Uyttenhove et al., "IL-9 induces differentiation of TH17 cells and enhances function of FoxP3 ${ }^{+}$ natural regulatory T cells," Proceedings of the National Academy of Sciences of the United States of America, vol. 106, no. 31, pp. 12885-12890, 2009.

[69] L. Codarri, G. Gyülvészii, V. Tosevski et al., "ROR $\gamma 3 t$ drives production of the cytokine GM-CSF in helper T cells, which is essential for the effector phase of autoimmune neuroinflammation," Nature Immunology, vol. 12, no. 6, pp. 560-567, 2011.

[70] M. El-Behi, B. Ciric, H. Dai et al., "The encephalitogenicity of $\mathrm{T}_{\mathrm{H}} 17$ cells is dependent on IL-1- and IL-23-induced production of the cytokine GM-CSF," Nature Immunology, vol. 12, no. 6, pp. 568-575, 2011.

[71] P. Miossec and J. K. Kolls, "Targeting IL-17 and $\mathrm{T}_{\mathrm{H}} 17$ cells in chronic inflammation," Nature Reviews Drug Discovery, vol. 11, no. 10, pp. 763-776, 2012.

[72] H. S. Bartlett and R. P. Million, "Targeting the IL-17- $\mathrm{T}_{\mathrm{H}} 17$ pathway," Nature Reviews Drug Discovery, vol. 14, no. 1, pp. 11-12, 2015.

[73] C. S. Constantinescu, A. Asher, W. Fryze et al., "Randomized phase $1 \mathrm{~b}$ trial of MOR103, a human antibody to GM-CSF, in multiple sclerosis," Neurology: Neuroimmunology \& Neuroinflammation, vol. 2, no. 4, pp. el17-e117, 2015.

[74] B. M. Segal, C. S. Constantinescu, A. Raychaudhuri, L. Kim, R. Fidelus-Gort, and L. H. Kasper, "Repeated subcutaneous injections of IL12/23 p40 neutralising antibody, ustekinumab, in patients with relapsing-remitting multiple sclerosis: a phase II, double-blind, placebo-controlled, randomised, dose-ranging study," The Lancet Neurology, vol. 7, no. 9, pp. 796-804, 2008.

[75] T. L. Vollmer, D. R. Wynn, S. M. Alam, and J. Valdes, "A phase 2, 24-week, randomized, placebo-controlled, double-blind study examining the efficacy and safety of an anti-interleukin-12 and -23 monoclonal antibody in patients with relapsing-remitting or secondary progressive multiple sclerosis," Multiple Sclerosis, vol. 17, no. 2, pp. 181-191, 2011.

[76] R. Martin, "Neutralisation of IL12 p40 or IL23 p40 does not block inflammation in multiple sclerosis," The Lancet Neurology, vol. 7, no. 9, pp. 765-766, 2008.

[77] J. R. Huh, M. W. L. Leung, P. Huang et al., "Digoxin and its derivatives suppress $\mathrm{T}$ H17 cell differentiation by antagonizing ROR $\gamma 3$ t activity," Nature, vol. 472, no. 7344, pp. 486-490, 2011.

[78] T. Xu, X. Wang, B. Zhong, R. I. Nurieva, S. Ding, and C. Dong, "Ursolic acid suppresses interleukin-17 (IL-17) production by selectively antagonizing the function of ROR $\gamma \mathrm{t}$ protein," The Journal of Biological Chemistry, vol. 286, no. 26, pp. 2270722710, 2011.

[79] L. A. Solt, N. Kumar, P. Nuhant et al., "Suppression of $\mathrm{T}_{\mathrm{H}} 17$ differentiation and autoimmunity by a synthetic ROR ligand," Nature, vol. 472, no. 7344, pp. 491-494, 2011.

[80] A. J. van Beelen, Z. Zelinkova, E. W. Taanman-Kueter et al., "Stimulation of the intracellular bacterial sensor NOD2 programs dendritic cells to promote interleukin-17 production in human memory T cells," Immunity, vol. 27 , no. 4, pp. $660-$ 669, 2007.
[81] N. C. Rogers, E. C. Slack, A. D. Edwards et al., "Syk-dependent cytokine induction by Dectin-1 reveals a novel pattern recognition pathway for C type lectins," Immunity, vol. 22, pp. 507-517, 2005.

[82] S. LeibundGut-Landmann, O. Gross, M. J. Robinson et al., "Sykand CARD9-dependent coupling of innate immunity to the induction of T helper cells that produce interleukin 17," Nature Immunology, vol. 8, no. 6, pp. 630-638, 2007.

[83] M. L. Kapsenberg, "Dendritic-cell control of pathogen-driven T-cell polarization," Nature Reviews Immunology, vol. 3, no. 12, pp. 984-993, 2003.

[84] C. Reis e Sousa, "Activation of dendritic cells: translating innate into adaptive immunity," Current Opinion in Immunology, vol. 16, no. 1, pp. 21-25, 2004.

[85] E. Bettelli, Y. Carrier, W. Gao et al., "Reciprocal developmental pathways for the generation of pathogenic effector $\mathrm{T}_{H} 17$ and regulatory T cells," Nature, vol. 441, no. 7090, pp. 235-238, 2006.

[86] P. R. Mangan, L. E. Harrington, D. B. O’Quinn et al., “Transforming growth factor- $\beta$ induces development of the $\mathrm{T}_{H} 17$ lineage," Nature, vol. 441, no. 7090, pp. 231-234, 2006.

[87] M. Veldhoen, R. J. Hocking, C. J. Atkins, R. M. Locksley, and B. Stockinger, "TGF $\beta$ in the context of an inflammatory cytokine milieu supports de novo differentiation of IL-17-producing T cells," Immunity, vol. 24, no. 2, pp. 179-189, 2006.

[88] R. Nurieva, X. O. Yang, G. Martinez et al., "Essential autocrine regulation by IL-21 in the generation of inflammatory T cells," Nature, vol. 448, no. 7152, pp. 480-483, 2007.

[89] M. Veldhoen, R. J. Hocking, R. A. Flavell, and B. Stockinger, "Signals mediated by transforming growth factor- $\beta$ initiate autoimmune encephalomyelitis, but chronic inflammation is needed to sustain disease," Nature Immunology, vol. 7, no. 11, pp. 1151-1156, 2006.

[90] L. Yang, D. E. Anderson, C. Baecher-Allan et al., "IL-21 and TGF- $\beta$ are required for differentiation of human $\mathrm{T}_{\mathrm{H}} 17$ cells," Nature, vol. 454, no. 7202, pp. 350-352, 2008.

[91] F. Gerosa, B. Baldani-Guerra, L. A. Lyakh et al., "Differential regulation of interleukin 12 and interleukin 23 production in human dendritic cells," The Journal of Experimental Medicine, vol. 205, no. 6, pp. 1447-1461, 2008.

[92] V. Soumelis and E. Volpe, "TH17 differentiation, a complex process in mouse and man," Medecine Sciences, vol. 24, no. 11, pp. 925-927, 2008.

[93] I. I. Ivanov, B. S. McKenzie, L. Zhou et al., "The orphan nuclear receptor RORgammat directs the differentiation program of proinflammatory IL-17 ${ }^{+}$T helper cells," Cell, vol. 126, no. 6, pp. 1121-1133, 2006.

[94] I. I. Ivanov, L. Zhou, and D. R. Littman, "Transcriptional regulation of Th17 cell differentiation," Seminars in Immunology, vol. 19, no. 6, pp. 409-417, 2007.

[95] Z. Chen, A. Laurence, Y. Kanno et al., "Selective regulatory function of Socs3 in the formation of IL-17-secreting T cells," Proceedings of the National Academy of Sciences of the United States of America, vol. 103, no. 21, pp. 8137-8142, 2006.

[96] L. Wei, A. Laurence, K. M. Elias, and J. J. O'Shea, "IL-21 is produced by Th17 cells and drives IL-17 production in a STAT3dependent manner," The Journal of Biological Chemistry, vol. 282, no. 48, pp. 34605-34610, 2007.

[97] L. de Beaucoudtey, A. Puel, O. Filipe-Santos et al., "Mutations in STAT3 and IL12RB1 impair the development of human IL-17producing T cells," The Journal of Experimental Medicine, vol. 205, no. 7, pp. 1543-1550, 2008. 
[98] A. Brüstle, S. Heink, M. Huber et al., "The development of inflammatory $\mathrm{T}(\mathrm{H})-17$ cells requires interferon-regulatory factor 4," Nature Immunology, vol. 8, no. 9, pp. 958-966, 2007.

[99] W. Ise, M. Kohyama, B. U. Schraml et al., "The transcription factor BATF controls the global regulators of class-switch recombination in both B cells and T cells," Nature Immunology, vol. 12, no. 6, pp. 536-543, 2011.

[100] B. U. Schraml, K. Hildner, W. Ise et al., "The AP-1 transcription factor Batf controls $\mathrm{T}_{\mathrm{H}} 17$ differentiation," Nature, vol. 460, no. 7253, pp. 405-409, 2009.

[101] M. Lohoff, H.-W. Mittrücker, S. Prechtl et al., "Dysregulated T helper cell differentiation in the absence of interferon regulatory factor 4," Proceedings of the National Academy of Sciences of the United States of America, vol. 99, no. 18, pp. 11808-11812, 2002.

[102] M. Ciofani, A. Madar, C. Galan et al., "A validated regulatory network for Th17 cell specification," Cell, vol. 151, no. 2, pp. 289303, 2012.

[103] X. O. Yang, B. P. Pappu, R. Nurieva et al., “T helper 17 lineage differentiation is programmed by orphan nuclear receptors ROR alpha and ROR gamma," Immunity, vol. 28, no. 1, pp. 2939, 2008.

[104] M. S. Sundrud and A. Rao, "Regulation of T helper 17 differentiation by orphan nuclear receptors: it's not just ROR $\gamma$ t anymore," Immunity, vol. 28, no. 1, pp. 5-7, 2008.

[105] K. A. Murphy, C. M. Villano, R. Dorn, and L. A. White, "Interaction between the aryl hydrocarbon receptor and retinoic acid pathways increases matrix metalloproteinase- 1 expression in keratinocytes," The Journal of Biological Chemistry, vol. 279, no. 24, pp. 25284-25293, 2004.

[106] D. Mucida, Y. Park, G. Kim et al., "Reciprocal TH17 and regulatory $\mathrm{T}$ cell differentiation mediated by retinoic acid," Science, vol. 317, no. 5835, pp. 256-260, 2007.

[107] M. Veldhoen, K. Hirota, A. M. Westendorf et al., "The aryl hydrocarbon receptor links TH17-cell-mediated autoimmunity to environmental toxins," Nature, vol. 453, no. 7191, pp. 106-109, 2008.

[108] F. J. Quintana, A. S. Basso, A. H. Iglesias et al., "Control of $\mathrm{T}_{\text {reg }}$ and $\mathrm{T}_{\mathrm{H}} 17$ cell differentiation by the aryl hydrocarbon receptor," Nature, vol. 453, no. 7191, pp. 65-71, 2008.

[109] E. V. Dang, J. Barbi, H.-Y. Yang et al., "Control of T(H)17/T(reg) balance by hypoxia-inducible factor 1," Cell, vol. 146, no. 5, pp. 772-784, 2011.

[110] L. Z. Shi, R. Wang, G. Huang et al., "HIF1 $\alpha$-dependent glycolytic pathway orchestrates a metabolic checkpoint for the differentiation of $\mathrm{T}_{\mathrm{H}} 17$ and $\mathrm{T}_{\text {reg }}$ cells," The Journal of Experimental Medicine, vol. 208, no. 7, pp. 1367-1376, 2011.

[111] M. J. McGeachy, K. S. Bak-Jensen, Y. Chen et al., "TGF- $\beta$ and IL6 drive the production of IL-17 and IL-10 by T cells and restrain $\mathrm{T}_{\mathrm{H}}$-17 cell-mediated pathology," Nature Immunology, vol. 8, no. 12, pp. 1390-1397, 2007.

[112] C. E. Zielinski, F. Mele, D. Aschenbrenner et al., "Pathogeninduced human TH17 cells produce IFN- $\gamma$ or IL-10 and are regulated by IL-1 $\beta$," Nature, vol. 484, no. 7395, pp. 514-518, 2012.

[113] Y. Gu, J. Yang, X. Ouyang et al., "Interleukin 10 suppresses Th17 cytokines secreted by macrophages and T cells," European Journal of Immunology, vol. 38, no. 7, pp. 1807-1813, 2008.

[114] M. O. Li and R. A. Flavell, "Contextual regulation of inflammation: a duet by transforming growth factor-beta and interleukin10," Immunity, vol. 28, no. 4, pp. 468-476, 2008.

[115] K. W. Moore, R. de Waal Malefyt, R. L. Coffman, and A. O'Garra, "Interleukin-10 and the interleukin-10 receptor," Annual Review of Immunology, vol. 19, pp. 683-765, 2001.
[116] D. Jankovic, D. G. Kugler, and A. Sher, "IL-10 production by $\mathrm{CD} 4^{+}$effector T cells: a mechanism for self-regulation," Mucosal Immunology, vol. 3, no. 3, pp. 239-246, 2010.

[117] A. Laurence, C. M. Tato, T. S. Davidson et al., "Interleukin2 signaling via STAT5 constrains T helper 17 cell generation," Immunity, vol. 26, no. 3, pp. 371-381, 2007.

[118] G. Ruocco, S. Rossi, C. Motta et al., "T helper 9 cells induced by plasmacytoid dendritic cells regulate interleukin-17 in multiple sclerosis," Clinical Science, vol. 129, no. 4, pp. 291-303, 2015.

[119] E. C. Nowak, C. T. Weaver, H. Turner et al., "IL-9 as a mediator of Th17-driven inflammatory disease," The Journal of Experimental Medicine, vol. 206, no. 8, pp. 1653-1660, 2009.

[120] C. Diveu, M. J. McGeachy, K. Boniface et al., "IL-27 blocks RORc expression to inhibit lineage commitment of Th17 cells," Journal of Immunology, vol. 182, no. 9, pp. 5748-5756, 2009.

[121] S.-C. Tang, X.-H. Fan, Q.-M. Pan, Q.-S. Sun, and Y. Liu, "Decreased expression of IL-27 and its correlation with Th1 and Th17 cells in progressive multiple sclerosis," Journal of the Neurological Sciences, vol. 348, no. 1-2, pp. 174-180, 2015.

[122] R. Milo and A. Miller, "Revised diagnostic criteria of multiple sclerosis," Autoimmunity Reviews, vol. 13, no. 4-5, pp. 518-524, 2014.

[123] C. H. Hawkes and G. Giovannoni, "The McDonald criteria for multiple sclerosis: time for clarification,” Multiple Sclerosis, vol. 16, no. 5, pp. 566-575, 2010.

[124] M. Koch, E. Kingwell, P. Rieckmann, and H. Tremlett, "The natural history of primary progressive multiple sclerosis," $\mathrm{Neu}$ rology, vol. 73, no. 23, pp. 1996-2002, 2009.

[125] A. Reboldi, C. Coisne, D. Baumjohann et al., "C-C chemokine receptor 6-regulated entry of $\mathrm{T}_{\mathrm{H}}-17$ cells into the $\mathrm{CNS}$ through the choroid plexus is required for the initiation of EAE," Nature Immunology, vol. 10, no. 5, pp. 514-523, 2009.

[126] H. Kebir, K. Kreymborg, I. Ifergan et al., "Human $\mathrm{T}_{\mathrm{H}} 17$ lymphocytes promote blood-brain barrier disruption and central nervous system inflammation," Nature Medicine, vol. 13, no. 10, pp. 1173-1175, 2007.

[127] M. Kostic, I. Stojanovic, G. Marjanovic, N. Zivkovic, and A. Cvetanovic, "Deleterious versus protective autoimmunity in multiple sclerosis," Cellular Immunology, vol. 296, no. 2, pp. 122132, 2015.

[128] Z. Kang, C. Wang, J. Zepp et al., "Actl mediates IL-17-induced EAE pathogenesis selectively in $\mathrm{NG}^{+}$glial cells," Nature Neuroscience, vol. 16, no. 10, pp. 1401-1408, 2013.

[129] M. K. Paintlia, A. S. Paintlia, A. K. Singh, and I. Singh, "Synergistic activity of interleukin-17 and tumor necrosis factor- $\alpha$ enhances oxidative stress-mediated oligodendrocyte apoptosis," Journal of Neurochemistry, vol. 116, no. 4, pp. 508-521, 2011.

[130] V. Siffrin, H. Radbruch, R. Glumm et al., "In vivo imaging of partially reversible th17 cell-induced neuronal dysfunction in the course of encephalomyelitis," Immunity, vol. 33, no. 3, pp. 424-436, 2010.

[131] Y. Komiyama, S. Nakae, T. Matsuki et al., "IL-17 plays an important role in the development of experimental autoimmune encephalomyelitis," Journal of Immunology, vol. 177, no. 1, pp. 566-573, 2006.

[132] H. H. Hofstetter, S. M. Ibrahim, D. Koczan et al., "Therapeutic efficacy of IL-17 neutralization in murine experimental autoimmune encephalomyelitis," Cellular Immunology, vol. 237, no. 2, pp. 123-130, 2005.

[133] C. Baecher-Allan, E. Wolf, and D. A. Hafter, "MHC class II expression identifies functionally distinct human regulatory $\mathrm{T}$ 
cells," Journal of Immunology, vol. 176, no. 8, pp. 4622-4631, 2006.

[134] J. Huehn and A. Hamann, "Homing to suppress: address codes for Treg migration," Trends in Immunology, vol. 26, no. 12, pp. 632-636, 2005.

[135] J. Haas, B. Fritzsching, P. Trübswetter et al., "Prevalence of newly generated naive regulatory $\mathrm{T}$ cells (Treg) is critical for Treg suppressive function and determines Treg dysfunction in multiple sclerosis," Journal of Immunology, vol. 179, no. 2, pp. 1322-1330, 2007.

[136] A. Croxford, M. Lanzinger, F. Hartmann et al., "The cytokine GM-CSF drives the inflammatory signature of $\mathrm{CCR}^{2+}$ monocytes and licenses autoimmunity," Immunity, vol. 43, no. 3, pp. 502-514, 2015.

[137] T. L. Vollmer, R. Liu, M. Price, S. Rhodes, A. La Cava, and F.-D. Shi, "Differential effects of IL-21 during initiation and progression of autoimmunity against neuroantigen," Journal of Immunology, vol. 174, no. 5, pp. 2696-2701, 2005.

[138] T. Korn, E. Bettelli, W. Gao et al., "IL-21 initiates an alternative pathway to induce proinflammatory $\mathrm{T}_{\mathrm{H}} 17$ cells," Nature, vol. 448, no. 7152, pp. 484-487, 2007.

[139] J. S. Tzartos, M. J. Craner, M. A. Friese et al., "IL-21 and IL21 receptor expression in lymphocytes and neurons in multiple sclerosis brain," The American Journal of Pathology, vol. 178, no. 2, pp. 794-802, 2011.

[140] G. Perriard, A. Mathias, L. Enz et al., "Interleukin-22 is increased in multiple sclerosis patients and targets astrocytes," Journal of Neuroinflammation, vol. 12, article 19, 2015.

[141] W. Xu, R. li, Y. Dai et al., "IL-22 secreting CD4 ${ }^{+} \mathrm{T}$ cells in the patients with neuromyelitis optica and multiple sclerosis," Journal of Neuroimmunology, vol. 261, no. 1-2, pp. 87-91, 2013.

[142] S. Rolla, V. Bardina, S. De Mercanti et al., "Th22 cells are expanded in multiple sclerosis and are resistant to IFN- $\beta$," Journal of Leukocyte Biology, vol. 96, no. 6, pp. 1155-1164, 2014.

[143] A. Goris, M. G. Marrosu, and K. Vandenbroeck, "Novel polymorphisms in the IL-10 related AK155 gene (chromosome 12q15)," Genes and Immunity, vol. 2, no. 5, pp. 284-286, 2001.

[144] S. Meller, J. Di Domizio, K. S. Voo et al., “TH17 cells promote microbial killing and innate immune sensing of DNA via interleukin 26," Nature Immunology, vol. 16, no. 9, pp. 970-979, 2015.

[145] P. Muranski, Z. A. Borman, S. P. Kerkar et al., “Th17 cells are long lived and retain a stem cell-like molecular signature," Immunity, vol. 35, no. 6, pp. 972-985, 2011.

[146] G. Shi, M. Ramaswamy, B. P. Vistica et al., "Unlike Thl, Th17 cells mediate sustained autoimmune inflammation and are highly resistant to restimulation-induced cell death," Journal of Immunology, vol. 183, no. 11, pp. 7547-7556, 2009.

[147] Y. Yu, C. Iclozan, T. Yamazaki et al., "Abundant c-Fas-associated death domain-like interleukin-1-converting enzyme inhibitory protein expression determines resistance of $\mathrm{T}$ helper 17 cells to activation-induced cell death," Blood, vol. 114, no. 5, pp. 10261028, 2009.

[148] M. T. Cencioni, S. Santini, G. Ruocco et al., "FAS-ligand regulates differential activation-induced cell death of human Thelper 1 and 17 cells in healthy donors and multiple sclerosis patients," Cell Death \& Disease, vol. 6, Article ID e1785, 2015.

[149] Y. K. Lee, H. Turner, C. L. Maynard et al., "Late developmental plasticity in the T helper 17 lineage," Immunity, vol. 30, no. 1, pp. 92-107, 2009.
[150] L. Maggi, M. Capone, F. Giudici et al., “CD4+CD161+ T lymphocytes infiltrate crohn's disease-associated perianal fistulas and are reduced by anti-TNF- $\alpha$ local therapy," International Archives of Allergy and Immunology, vol. 161, no. 1, pp. 81-86, 2013.

[151] R. Duhen, S. Glatigny, C. A. Arbelaez, T. C. Blair, M. Oukka, and E. Bettelli, "Cutting edge: the pathogenicity of IFN- $\gamma$-producing Th17 cells is independent of T-bet," Journal of Immunology, vol. 190, no. 9, pp. 4478-4482, 2013.

[152] D. O. Adams, "Molecular interactions in macrophage activation," Immunology Today, vol. 10, no. 2, pp. 33-35, 1989.

[153] B. Ajami, J. L. Bennett, C. Krieger, K. M. McNagny, and F. M. V. Rossi, "Infiltrating monocytes trigger EAE progression, but do not contribute to the resident microglia pool," Nature Neuroscience, vol. 14, no. 9, pp. 1142-1149, 2011.

[154] K. P. Garnock-Jones, "Secukinumab: a review in moderate to severe plaque psoriasis," American Journal of Clinical Dermatology, vol. 16, no. 4, pp. 323-330, 2015.

[155] I. B. McInnes, P. J. Mease, B. Kirkham et al., "Secukinumab, a human anti-interleukin-17A monoclonal antibody, in patients with psoriatic arthritis (FUTURE 2): a randomised, doubleblind, placebo-controlled, phase 3 trial," The Lancet, vol. 386, no. 9999, pp. 1137-1146, 2015.

[156] W. Hueber, B. E. Sands, S. Lewitzky et al., "Secukinumab, a human anti-IL-17A monoclonal antibody, for moderate to severe Crohn's disease: unexpected results of a randomised, double-blindplacebo-controlled trial," Gut, vol. 61, no. 12, pp. 1693-1700, 2012.

[157] I. A. Ferber, S. Brocke, C. Taylor-Edwards et al., "Mice with a disrupted IFN- $\gamma$ gene are susceptible to the induction of experimental autoimmune encephalomyelitis (EAE)," Journal of Immunology, vol. 156, no. 1, pp. 5-7, 1996.

[158] E. Bettelli, B. Sullivan, S. J. Szabo, R. A. Sobel, L. H. Glimcher, and V. K. Kuchroo, "Loss of T-bet, but not STAT1, prevents the development of experimental autoimmune encephalomyelitis," The Journal of Experimental Medicine, vol. 200, no. 1, pp. 79-87, 2004.

[159] B. Gran, G.-X. Zhang, S. Yu et al., "IL-12p35-deficient mice are susceptible to experimental autoimmune encephalomyelitis: evidence for redundancy in the IL-12 system in the induction of central nervous system autoimmune demyelination," Journal of Immunology, vol. 169, no. 12, pp. 7104-7110, 2002. 


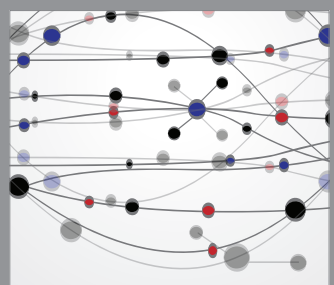

The Scientific World Journal
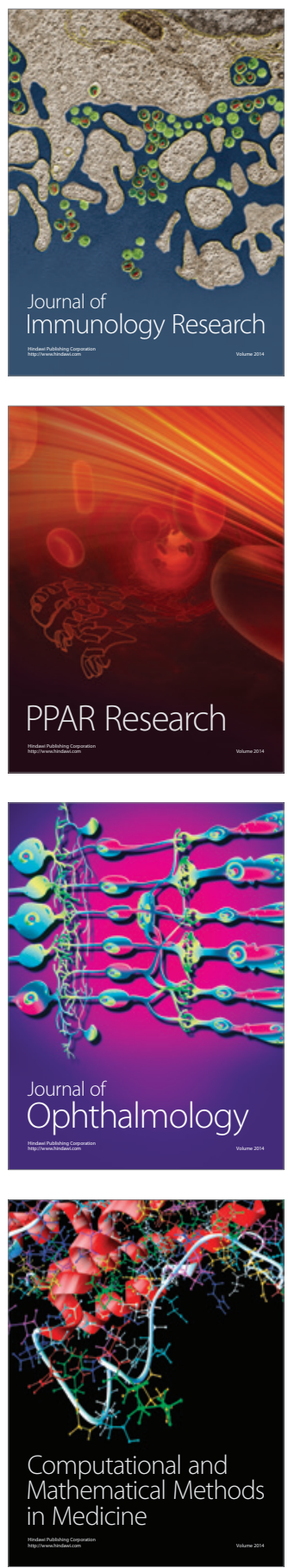

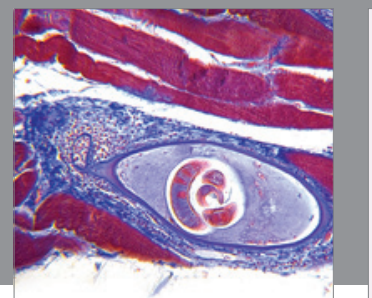

Gastroenterology

Research and Practice
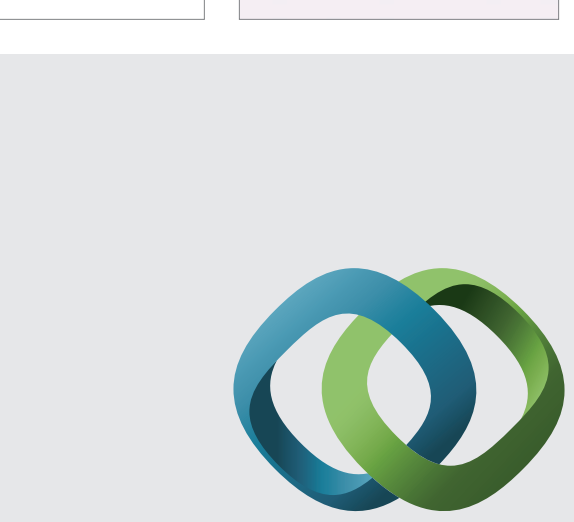

\section{Hindawi}

Submit your manuscripts at

http://www.hindawi.com
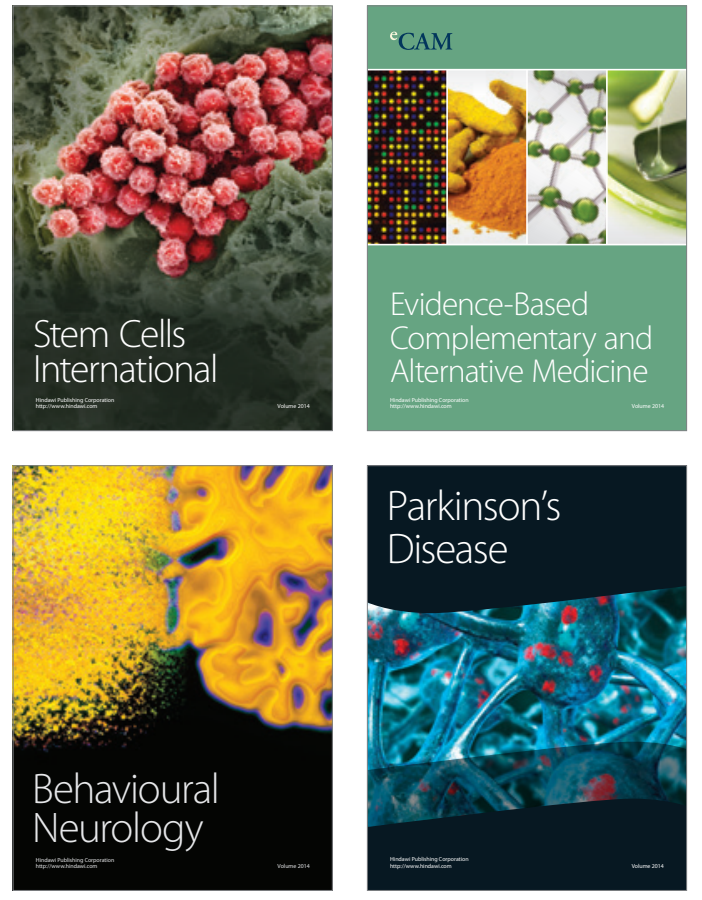
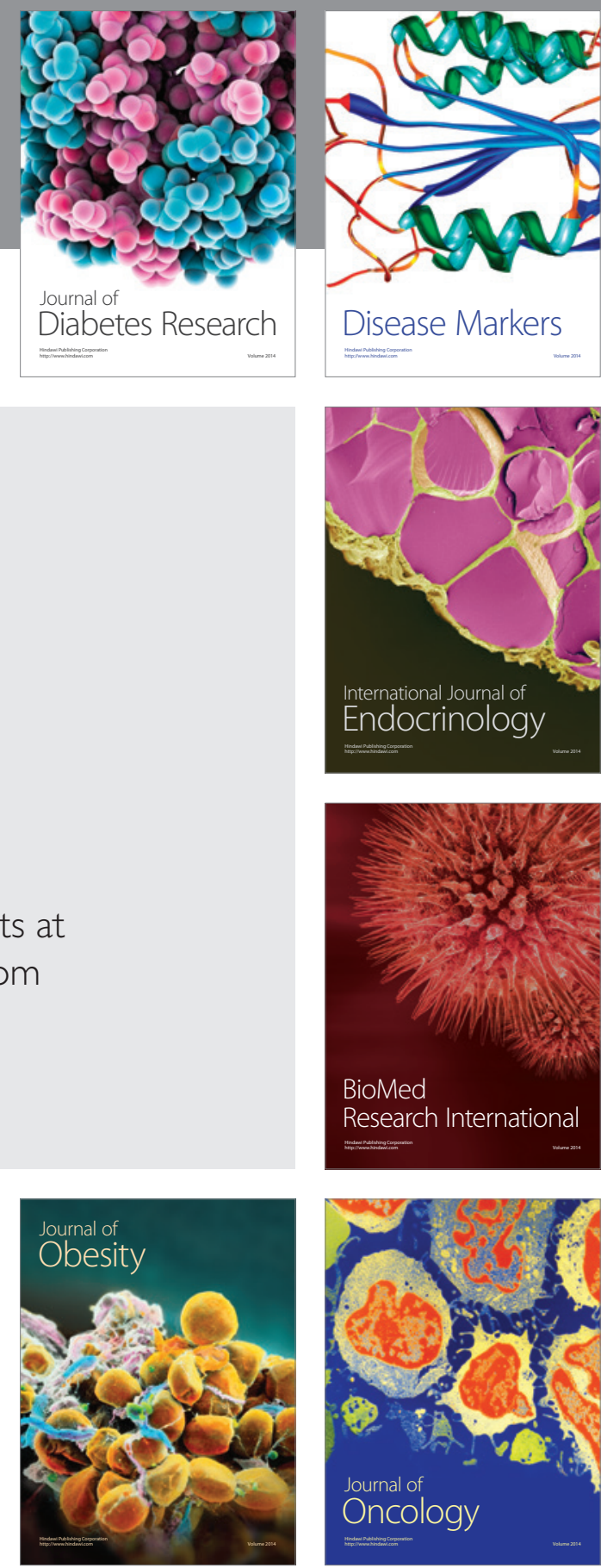

Disease Markers
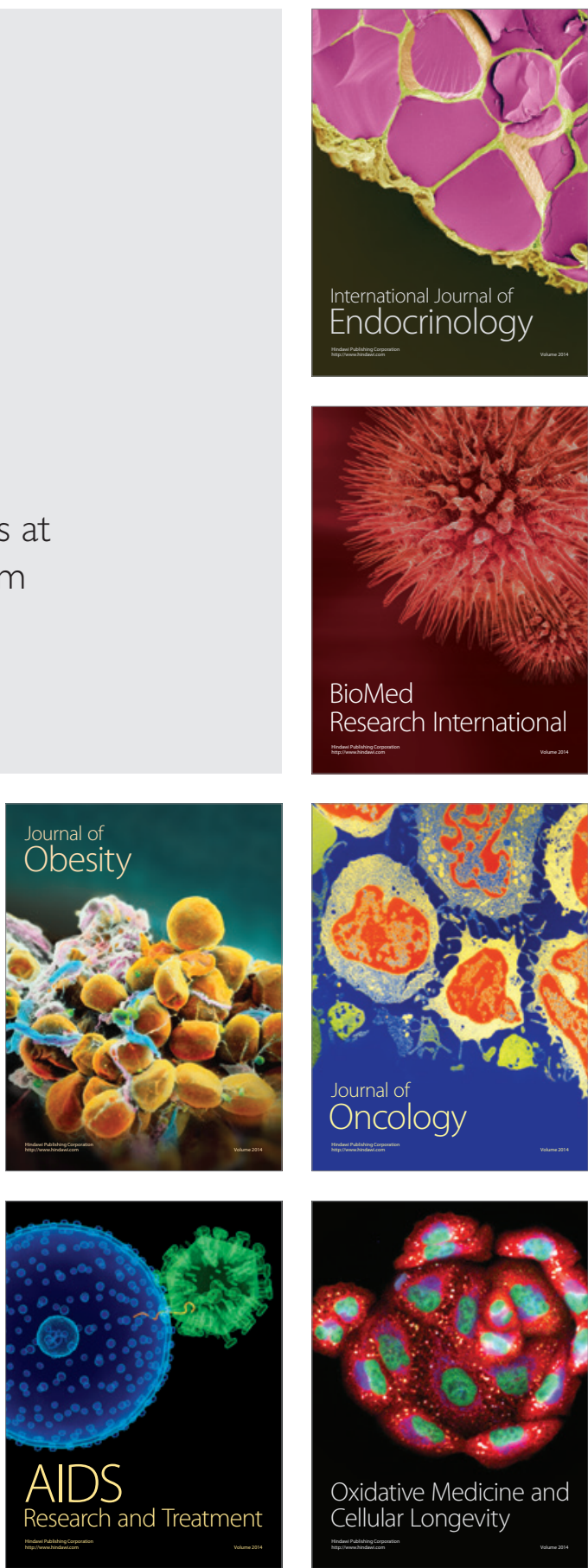